\title{
Information Safety and Issues of Its Provision in the Business Environment
}

\author{
Yakovlev V.A.* Semyonova A.N \\ Federal State Autonomous Educational Institution for Higher Education "Ammosov North-Eastern Federal University", \\ Russia, the Republic of Sakha (Yakutia), Yakutsk, 58 Belinskogo St. \\ *Corresponding author. Email: febra.t@yandex.ru
}

\begin{abstract}
Issues of the state information resources safety are set forth in the Doctrine of Russian Information Resources Safety. Exactly for this reason, when considering the provision of information safety in the field of business and commercial activity, first of all, the attention should be paid to the main information safety requirements, to the regulatory and legal basis in the field of information safety, availability of the existing technology basis and technical means for database protection provision, and considering the fundamentals of information resources safety.

The relevance of this subject is of great importance because it frequently happens in the country that people who dedicated their activity to business or commerce, face the issue of providing their personal data safety and the trade secret.

In addition, two main issues will be studied in this paper in details:

- information war issue;

- information terrorism issue.

In addition, an issue of information safety in economic activity and features of the ways of its solution will be studied in this paper.
\end{abstract}

Keywords: information, safety, protection, access, trade secret, bank secret

\section{INTRODUCTION}

Information is crucial in the history of development of human civilization. Owning the information is the main prerequisite for the progressive social development. Distortion of information data, blocking the information receipt process or deliberate introduction of false information are phenomena contributing to making erroneous decisions.

For the time being, the society development can be characterized by the need for information processes required for the provision of work of state power authorities, civil organizations, and life of people.

Information is present in any field of public production. Information is the initial cycle concerning any product, the completed work or the service provided.

information safety is crucial in economic activity because the data leakage can cause the formation of numerous problems, including legal and economic troubles. This is the topicality of the research paper selected subject.

The objective of this research paper is studying the features of providing information safety in economic activity.

In terms of the objective selected, the list of the following tasks has been solved in the paper:
1. Consideration of fundamental of information safety in economic activity;

2. Characteristics of legal instruments of information protection in economic activity;

3. Determination of features of technical instruments of information data protection in economic activity.

4. The notion of the information safety, fundamentals of information resources safety in economic activity

5. The notion of the information safety, fundamentals of information resources safety in business

2. NOTION OF INFORMATION SAFETY, FUNDAMENTALS OF INFORMATION RESOURCES SAFETY IN BUSINESS

\subsection{Notion and problems of information safety}

Information in legal aspect traditionally means data about persons, facts, items, processes, phenomena and events independently on the form of their representation. Information is a non-material object; at this, its fixation can be fulfilled on hard copies - paper, magnet, and the 
others. Its specific is in the fact that it can be distributed, handled, applied, used in various forms, consumed freely and without limits, without any impact on its properties.

The present existence of business cannot be imagined without information. Information has become a common way of business conduct to everyone.

At this, the information can be the result of a goal-seeking intellectual labor (in other words, as the result of the intellectual activity). At this, information as the special type of civil rights, differing from the results of intellectual (creative) activity, conventionally means information (data), not regulated by the legal regime of protecting the standards of author, patent, or another special legislation. Free access to information can be limited in the case if it represents data that are the trade secret, due to which, this information is subject to the special protection regime.

Three central directions are set for information protection, applied in economic activity:

1. Protection of the company professional reputation and honor, protection from the threat of the impact of low quality of harmful information, unreliable or false data, breaking the procedure of information data distribution, and so on.

2. Protection of information in the form of limited access to the information resource (all secret formats: bank or state). Protection of information systems and technologies from the illegal or unauthorized actions of the third party.

3. Protection of information rights (ownership to the information resource and documents, to information technologies, and so on) in the informatization conditions.

Information data protection is represented by technical measures aimed at:

1. Provision of the information data safety, excluding the illegal access to data, their modification or destruction, transfer or copying, and blocking the data source;

2. Following the procedure of providing the confidentiality of information data that are available in limited access;

3. Implementation of the user's right to open access to information [1].

Any information is subject to the protection from illegal use that can cause damage to the data owner or user. Information being protected is the information being the property item. It is subject to protection in terms of provisions reflected in legal documents, or according to the requirements set by an information resource owner or a data owner.

Information protection provision is carried out with the objective to prevent:

1. Leakages (information distribution due to the illegal access by intelligence teams);

2. Illegal actions (impact on the protected information. Breaking standards and rules of the information change and use that will cause its distortion, or access blocking for a user);

3. Indeliberate effect on information (effect on information being protected due to errors in user's work, software failures, natural phenomena and other factors not provided for deliberate effect on information. At this, such factors lead to the information copying, distortion, source blocking and data destruction);

4. Disclosure of information data (illegal data distribution among consumers that have no access to the certain information);

5. Illegal access (receipt of protected data by an interested person with the breach of the established rules of information use);

6. Intelligence (obtaining of information by agent teams of technical intelligence) [2].

\subsection{Legal instruments of information data protection in economic activity}

Information protection is a procedure designated for data access. It provides for the liability for the illegal information use. Information protection in economic activity can exist in relation to:

1. Secret;

2. Confidential data;

3. Personal data [3].

Secret shall mean information with the restricted access in terms of the state legislation. The legislator established the imposition of legal liability on a person who carried out the unauthorized use of such information.

Confidential data are the information not subject to disclosure, that can be used only by persons that are directly related to it.

Personal data mean the information relating to the specific physical entity because it reflects his/her private data.

National legislation provides for numerous data types that can be covered by the information protection procedure. The most common in economic activity are:

1. Trade secret is the confidentiality of data that enable their owner to gain the income volume while avoiding ungrounded expenses, at any time, saving the status of his/her company at the market, or acquire different benefit of commercial nature.

2. Bank secret is the information about bank operations, deposits and correspondent accounts, the credit company customers, the activity of the Bank of Russia and other organizations carrying out the functionality in relation to the obligatory insurance of customers' deposits.

Information data that compose the trade secret include the following data types:

- scientific and technical information;

- technical information; 
- production information;

- financial and economic information;

- other information types that have the potential commercial value as the result of the closed data access for the third parties that have no legal grounds for using such information [4].

Information, that constitutes the trade secret, if it was transferred for possession by the owner himself/herself based on the agreement or another document is the information received on legal grounds. If the data were received in the course of deliberate overcoming of protection measures taken by the information owner, they obtain the status of the data received illegally. Similarly, in the case when the third party, who received access to the commercial information, knew that the data are the trade secret subject, any action with the information use is a legal offence [5].

Certainly, not all information can be subject to protection in the trade secret regime because the company is obliged to make the considerable amount of data public.

For example, according to the state legislation, the following information is not subject to the trade secret regimen:

- data contained in the statutory package of the legal entity's documents, and in documents confirming the fact of entering records about the legal entity or the sole proprietor into the state registry;

- data contained in the documents confirming the right for commercial activity conduct;

- environment pollution data, information about the company fire safety, radiation and sanitary and epidemiological state of the object, food products safety and other factors that may have a negative impact on the provision of the commercial object safe functioning, and civil safety;

- information about the company debit and credit debt, and data on salary debts;

- data about breaches of statutory and legal acts of the Russian legislation and facts of liability imposing on the establishment due to the violation;

- data about auctions or tenders for objects privatization from municipal or state property;

- data about persons with the right of carrying out business activity as the legal entity representative without a power of attorney;

- data, the obligation to disclose which or the impermissibility to limit the access to which is set by the national legislation [3].

Bank secret is the information about deposits and customer accounts, and data of correspondents of credit organizations, information about the conduct of bank transaction and other operations. Credit companies that perform functions of obligatory insurance of client deposits, guarantee the confidentiality of information about all the clients' operations, deposits, and customer accounts. The company employees are also obliged to keep the secret [6].

Certificates on accounts and operations of a sole entrepreneur or a legal entity can be issued by the credit company to them in person, or delivered to a court institution, Auditing Chamber, local tax office, Pension Fund, Social Insurance Fund, officer of justice, or a preliminary investigation agency.

Concerning documents belonging to the physical entity, the credit company may issue it to the physical entity himself/herself, the court institution, court decision enforcement agency or other organs and authorized persons that carry out activities for mandatory insurance of customer deposits subject to the event insured occurrence ( [7].

If the bank account or the bank deposit owner dies, documents will be issued to persons specified by the previous owner in his/her will. In the case of a deceased foreign citizen, all information will be transferred to the consular department. [8].

In cause of the bank secret illegal disclosure, Central bank of Russian Federation and organizations that insure the deposits, along with the other credit and audit companies are held liable for the damage caused [9].

Personal data are any information data relating to the specific physical entity. They contain personal data [10].

In the field of economic activity, such information is very important because, if the employee's personal data leak, the injured party is justified to commence an action.

The data confidentiality regime can be applied to personal information.

This regime is inapplicable to personal data available from public sources.

If the subject of personal information gave a written consent for placement of his/her data in public sources, any private information can be published with public access (telephone numbers, full name, place of residence, etc.).

This information can be removed from open access if its owner requests to delete the data. In addition, the information can be extracted by the decision of a court or the other state organizations [8].

For the breach of the information data safety regimen, legal liability is imposed in terms of the state legislation. For example, the illegal data receipt with their subsequent disclosure took place. These data are a bank or a trade secret. Such action is a criminal offence, for committing which the guilty person should be imposed the respective liability: from monetary penalty to the term of imprisonment [11].

Administrative liability is imposed for breaking the legal procedure of collection, transfer, storage and use of data kept in limited access, breaking the information safety rules, etc. [12].

\section{CONCLUSION}

Based on the aforementioned, I made the following conclusions.

Information safety in economic activity can be achieved by applying the system of measures aimed at the data protection provision. 
The organization measures are based on documented procedures and rules of work with various information types, IT services, and tools.

Technical measures are represented by the control function work in relation to software and hardware tools for opening access to data, monitoring of possible information leakages and operation of anti-virus programs, firewalling, and so on.

Tasks of information data protection in economic activity system are various. It is represented by:

- provision of information data storage on various carriers; - protection of information transferred via communication channels;

- division of access to various data types;

- creating the information backup copy;

- data disaster recovery, and so on.

Provision of information data safety in economic activity is possible only if the complex approach is used. The information safety system should account for all risks and threats.

Comprehensive safety of commercial information obliges the company to carry out permanent control over all events and procedures that could influence the data safety. Protection should be carried out daily and without interruptions, covering the entire life cycle of information data: from their delivery to the company to destruction.

\section{ACKNOWLEDGMENT}

I, Semyonova Avelina Nikifororvna, would like to express my sincere gratitude to my research advisor, Yakovlev Valeriy Aleksandrovich, for his help in searching literature sources that became the basis for writing this research paper.

\section{REFERENCES}

[1] Federal'nyj zakon «Ob informacii, informacionnyh tekhnologiyah i o zashchite informacii» ot 27.07.2006 N 149-FZ - st. 16.

[2] Konin N. M. Informacionnoe pravo: uchebnik / N. M. Konin, E. I. Matorina. - M.: Izdatel'stvo YUrajt, 2015. — S, 412.

[3] Federal'nyj zakon «O kommercheskoj tajne» ot 29.07.2004 N 98-FZ - st. 3.

[4] Kopytov YU. A. Informacionnoe pravo: uchebnik / YU. A. Kopytov. - 2-e izd., pererab. i dop. - M.: Izdatel'stvo YUrajt, 2015. - S. 366.

[5] SHiverskij A.A. Zashchita informacii: problemy teorii i praktiki. / A.A. SHiverskij - M.: YUrist", 2015. - 177 s.
[6] Federal'nyj zakon «O bankah i bankovskoj deyatel'nosti» ot 02.12.1990 N 395-1-FZ - st. 26.

[7] Agapov A. B. Informacionnoe pravo: uchebnik / A. B. Agapov. - 9-e izd., pererab. i dop. - M.: Izdatel'stvo YUrajt, 2016. - S. 482.

[8] Zakupen' T.V., Sobol' S.YU. Informaciya i ee pravovoe regulirovanie // ZHurnal rossijskogo prava. 2016. - № 1 .

[9] Grazhdanskij kodeks Rossijskoj Federacii (chast' vtoraya) ot 26.01.1996 N 14-FZ- st. 857.

[10] Federal'nyj zakon «O personal'nyh dannyh» ot 27.07.2006 N 152-FZ - st. 3.

[11] Ugolovnyj kodeks Rossijskoj Federacii ot 13.06.1996 N 63-FZ- st. 183.

[12] Kodeks Rossijskoj Federacii ob administrativnyh pravonarusheniyah ot $30.12 .2001 \mathrm{~N}$ 195-FZ- st. 13.11, 14.14, 13.12 